\title{
The frequency of type 2 second-degree and third-degree atrioventricular block induced by blunt chest trauma in the emergency department: A multicenter study
}

\author{
Banu Şahin Yıldız, M.D., ${ }^{1}$ Mehmet Ali Astarcıoğlu, M.D., ${ }^{2}$ Nazire Başkurt Aladağ, M.D., ${ }^{1}$ \\ Ahmet Çağrı Aykan, M.D., ${ }^{3}$ Hakan Hasdemir, M.D., ${ }^{4}$ Alparslan Şahin, M.D., ${ }^{5}$ Mustafa Yıldız, M.D. ${ }^{3}$
}

\begin{abstract}
${ }^{1}$ Department of Internal Medicine, Dr. Lütfi Kırdar Kartal Training and Research Hospital, İstanbul
${ }^{2}$ Department of Cardiology, Dumlupınar University Evliya Çelebi Training and Research Hospital, Kütahya

${ }^{3}$ Department of Cardiology, Kartal Koşuyolu Yüksek Ihtisas Training and Research Hospital, İstanbul

${ }^{4}$ Department of Cardiology, Dr. Siyami Ersek Cardiovascular and Thoracic Surgery Training and Research Hospital, İstanbul

${ }^{5}$ Department of Cardiology, Dr. Sadi Konuk Training and Research Hospital, İstanbul
\end{abstract}

\begin{abstract}
BACKGROUND: Conduction disturbances including type 2 second-degree atrioventricular block (Mobitz II) and third-degree atrioventricular block following blunt chest trauma are probably rare. Moreover, the pathophysiological mechanisms responsible for this rare dysrhythmia following trauma are not well understood yet. In this study, it was aimed to identify the frequency of this dysrhythmia associated with trauma.
\end{abstract}

METHODS: Two hundred and fifty-three consecutive Mobitz II block and third-degree atrioventricular block patients admitted to the Emergency Department of Internal Medicine between January 2012 and March 20I3 were evaluated. Only four patients with Mobitz II block and third-degree atrioventricular block associated with trauma were enrolled into the present study. The level of atrioventricular block was defined according to electrocardiographic characteristics.

RESULTS: Only four (mean age: $40.2 \pm 19.7$ years, two male) of 253 patients were associated with trauma. All patients had normal coronary arteries in coronary angiography or multislice computed tomography. Permanent pacemaker was performed in two patients with third-degree atrioventricular block. None of the patients had coronary artery disease or hypertension.

CONCLUSION: Rare clinical cases in the literature confirm that blunt chest trauma can cause conduction defects, which are usually transient. However, patients with blunt chest trauma must need an electrocardiographic evaluation for atrioventricular block upon admission and in the follow-up period.

Key words: Blunt chest trauma; electrocardiography; third-degree atrioventricular block; Type 2 second-degree atrioventricular block (Mobitz II).

\section{INTRODUCTION}

Blunt chest trauma is a significant cause of morbidity and mortality in life. It can affect chest wall and thoracic cav-

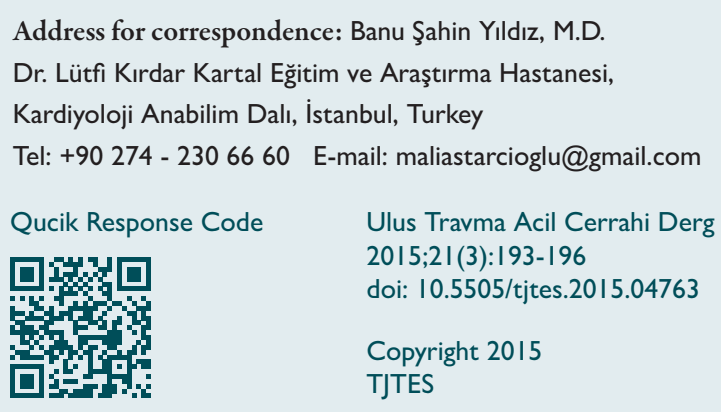

ity including the clavicles, ribs, esophagus, lungs, and heart. [I] It may cause cardiac lesions in coronary arteries, valves and pericardium. Depending on the extent of trauma, such injuries can cause varying amounts of mechanical or electrical dysfunction including high degree atrioventricular block and ventricular fibrillation. ${ }^{[2]}$ There are still limited data regarding the incidence, prevalence and clinical characteristics of important dysrhythmia including type 2 second-degree atrioventricular block (Mobitz II) and third-degree atrioventricular block following trauma. ${ }^{[2-4]}$ Moreover, the pathophysiological mechanisms responsible for this rare dysrhythmia following trauma are not well understood yet.

The aim of this present study was to identify the frequency of the Mobitz II block and third-degree atrioventricular block 
associated with trauma in the Emergency Department of Internal Medicine. The dysrhythmia was also assessed for the necessity of permanent pacemaker.

\section{MATERIALS AND METHODS}

Two hundred and fifty-three consecutive Mobitz II block and third-degree atrioventricular block patients admitted to the Emergency Department of Internal Medicine between January 2012 and March 2013 were evaluated. Only four patients with Mobitz II block (two patients) and third-degree atrioventricular block (two patients) were associated with trauma, and those four patients were enrolled into the present study. The study was approved by the local committee. All subjects gave their consent for inclusion into the study. The investigation conformed to the principles outlined in the Declaration of Helsinki. Patients with electrolyte abnormalities, digitalis toxicity, vasovagal syncope, myocardial infarction history, and patients using drugs, which might affect atrioventricular node, were excluded from the study.

The level of atrioventricular block was defined according to the following electrocardiographic characteristics: Type 2 second-degree atrioventricular block (Mobitz II): Mobitz II heart block is characterized on a surface electrocardiography by intermittently non-conducted $P$ waves not preceded by PR prolongation and not followed by PR shortening. The block may progress rapidly to third-degree atrioventricular block.

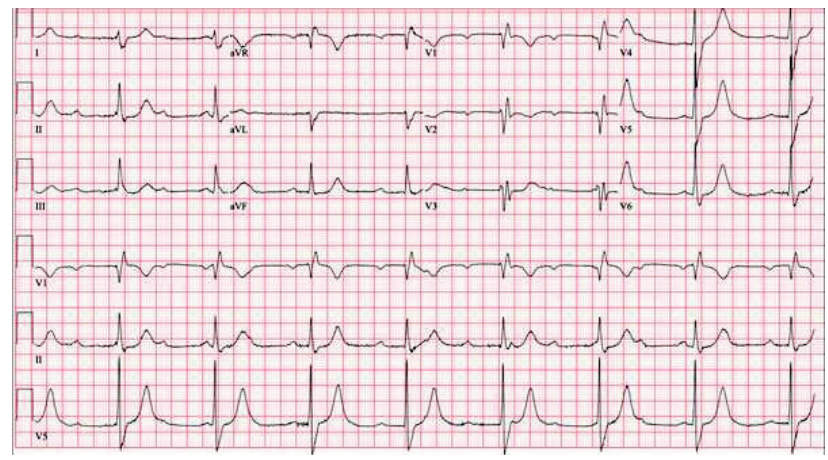

Figure 1. The patient with Mobitz II block after blowing the soccer ball.

Third-degree atrioventricular block or complete heart block: This is a medical condition in which the impulse generated in the sinoatrial node in the atrium does not propagate to the ventricles. The PR interval will be variable as the hallmark of complete heart block is no apparent relationship between $\mathrm{P}$ waves and QRS complexes.

\section{RESULTS}

Only four patients (mean age: $40.2 \pm 19.7$ years, two male) with Mobitz II block (two female patients) (Fig. I) and thirddegree atrioventricular block (two male patients) were associated with trauma. All patients had normal coronary arteries in coronary angiography or multislice computed tomography. Permanent pacemaker was performed in two patients with

Table I. Baseline clinical and electrocardiographic characteristics and treatment of patients with atrioventricular block

\begin{tabular}{|c|c|c|c|c|}
\hline Patient & 1 & 2 & 3 & 4 \\
\hline Age (years) & 40 & 68 & 30 & 23 \\
\hline Sex & Male & Female & Female & Male \\
\hline Event & $\begin{array}{l}\text { Blunt chest and head } \\
\text { trauma after a robbery }\end{array}$ & Automobile accident & $\begin{array}{l}\text { Blow with } \\
\text { soccer ball }\end{array}$ & Blow with soccer ball \\
\hline $\begin{array}{l}\text { Symptoms and starting } \\
\text { time after trauma }\end{array}$ & $\begin{array}{l}\text { Dizziness and syncope; } \\
2 \text { days }\end{array}$ & $\begin{array}{l}\text { Chest pain, dyspnea, } \\
\text { dizziness; immediately }\end{array}$ & $\begin{array}{l}\text { Dizziness; } \\
\text { immediately }\end{array}$ & Pre-syncope; immediately \\
\hline Risk factors for dysrhythmia & - & - & - & - \\
\hline Using drugs & - & - & - & - \\
\hline Electrocardiogram & Complete AV block & $\begin{array}{l}\text { Mobitz II block progressed } \\
\text { to complete AV block } \\
\text { on day } 3\end{array}$ & $\begin{array}{l}\text { Mobitz } \\
\text { II block }\end{array}$ & Complete AV block \\
\hline $\begin{array}{l}\text { RBBB on the } \\
\text { electrocardiography }\end{array}$ & + & - & - & - \\
\hline Hemo-pericardium & - & - & - & - \\
\hline Heart valve injury & - & Tricuspide valve & - & - \\
\hline Treatment & $\begin{array}{l}\text { Dual-chamber rate-adaptive } \\
\text { (DDDR) pacemaker }\end{array}$ & Medical & Medical & $\begin{array}{l}\text { Dual-chamber rate-adaptive } \\
\text { (DDDR) pacemaker }\end{array}$ \\
\hline
\end{tabular}


third-degree atrioventricular block. None of the patients had history of any disease like coronary artery disease and hypertension. Baseline clinical and electrocardiographic characteristics and treatment of patients with atrioventricular block are shown in Table I.

\section{DISCUSSION}

In this study, it was found that only four of 253 consecutive Mobitz II block and third-degree atrioventricular block patients, admitted to the Emergency Department of Internal Medicine, were associated with blunt chest trauma. The occurrence of myocardial contusion after blunt chest trauma varies between 8 and $76 \%$ according to the clinical criteria used for diagnosis. Traffic accidents are the most common cause, although it has also been described in sport accidents, kicks from animals, falls and cardiac resuscitation maneuvers. [1] These injuries may result from lacerations to valve rupture, myocardial rupture with tamponade, acute myocardial infarction following coronary arteries thrombosis and/or dissection, arrhythmia like ventricular fibrillation and myocardial contusion which may result in dysrhythmias and blocks generally bifascicular or right bundle branch; however, constituting complete $\mathrm{AV}$ block is a rare complication. ${ }^{[2-7]}$ Although the occurrence of complete AV block is common in traumatic experimental models, it is an exceptional observation in clinical practice. Although the exact cause of these disorders is unknown, various mechanisms have been proposed, such as the appearance focal hemorrhages in the region of the atrioventricular node, localized hypoxia specific conduction tissue, increased vagal tone or release of depressants of the conduction system. Pathologic changes associated with blunt trauma induced by conduction disturbances are variable. ${ }^{[8,9]}$ Generally, no pathologic changes were found, despite findings of repolarization changes, conduction defects and dysrhythmias. Conduction disturbances might be associated with inflammation. Several inflammatory mediators such as interleukin-6, tumor necrosis factor, and prostanoids are released following blunt chest trauma. ${ }^{[10-12]}$ Moreover, scar tissue formation during the healing process may cause late complications like atrioventricular block in myocardial blunt trauma. ${ }^{[13]}$

Case I had normal sinus rhythm in electrocardiography before the event and demonstrated symptomatic complete atrioventricular block with right bundle branch morphology after blunt chest trauma. His echocardiography was normal in terms of trauma. Atrioventricular block may be associated with fibrosis affecting the conduction system as part of the healing process after myocardial injury. While complete atrioventricular block reoccurred after four months and became permanent, the dual-chamber rate-adaptive (DDDR) -mode pacemaker was implanted and the patient had an uneventful recovery. In Case 2, electrocardiography was consistent with Mobitz II block on admission, which subsequently progressed to complete atrioventricular block on day 3. Furthermore, severe tricuspid regurgitation with chordae tendineae rupture was seen in the transthoracic echocardiography. During follow-up with close hemodynamic monitoring, her symptoms disappeared and sequential echocardiographic evaluations revealed a regression in the severity of tricuspid regurgitation. Finally, she was discharged with medical therapy about one week later. During her follow-ups, electrocardiography revealed normal sinus rhythm. In Case 3 (a female footballer), admission electrocardiography was consistent with Mobitz II block alternating sinus rhythm after receiving a blow with the soccer ball. Holter rhythm monitoring, echocardiography and electrophysiological study revealed in normal range. After 12 months of follow-up, as she was athletic, she had no specific cardiovascular symptoms. In addition, she had normal electrocardiography. Case 4 was also admitted with complete atrioventricular block after receiving a blow with the soccer ball. His echocardiography was normal in terms of trauma. While complete atrioventricular block reoccurred after two weeks and became permanent, the DDDR mode pacemaker was implanted and the patient had an uneventful recovery. Baseline clinical and electrocardiographic characteristics and treatment of the patients with atrioventricular block were shown in Table I.

Rare clinical cases in the literature confirm that blunt chest trauma can cause conduction defects and that these defects are usually transient, as they were in our study. However, patients with blunt chest trauma must need an electrocardiographic evaluation for atrioventricular block upon admission and in the follow-up period.

Conflict of interest: None declared.

\section{REFERENCES}

1. Calhoon JH, Grover FL, Trinkle JK. Chest trauma. Approach and management. Clin Chest Med 1992;13:55-67.

2. Brennan JA, Field JM, Liedtke AJ. Reversible heart block following nonpenetrating chest trauma. J Trauma 1979;19:784-8. CrossRef

3. Hasdemir H, Arslan Y, Alper A, Osmonov D, Güvenç TS, Poyraz E, et al. Severe tricuspid regurgitation and atrioventicular block caused by blunt thoracic trauma in an elderly woman.J Emerg Med 2012;43:445-7. CrossRef

4. Aykan AC, Oguz AE, Yildiz M, Özkan M. Complete atrioventricular block associated with non-penetrating cardiac trauma in a 40-year-old man. J Emerg Med 2013;44:41-3. CrossRef

5. Kumagai H, Hamanaka Y, Hirai S, Mitsui N, Kobayashi T. Mitral valve plasty for mitral regurgitation after blunt chest trauma. Ann Thorac Cardiovasc Surg 2001;7:175-9.

6. Sakka SG, Hüttemann E, Reinhart K. Left ventricular aneurysm after myocardial contusion caused by blunt chest trauma. [Article in German] Anasthesiol Intensivmed Notfallmed Schmerzther 2000;35:412-6. [Abstract] CrossRef

7. Ildstad ST, Tollerud DJ, Weiss RG, Cox JA, Martin LW. Cardiac contusion in pediatric patients with blunt thoracic trauma. J Pediatr Surg 1990;25:287-9. CrossRef

8. Carr KW, Johnson AD, Gregoratos G. Transient bifascicular block following blunt chest trauma. West J Med 1982;137:245-9.

9. Cobanoglu U. Göğüs travmalı 70 olguda kardiyolojik değişikliklerin incelenmesi. Toraks Dergisi 2007;8:59-68. 
10. Knöferl MW, Liener UC, Seitz DH, Perl M, Brückner UB, Kinzl L, et al. Cardiopulmonary, histological, and inflammatory alterations after lung contusion in a novel mouse model of blunt chest trauma. Shock 2003;19:519-25. CrossRef

11. Perl M, Kieninger M, Huber-Lang MS, Gross HJ, Bachem MG, Braumüller S, et al. Divergent effects of activated neutrophils on inflammation, Kupffer cell/splenocyte activation, and lung injury following blunt chest trauma. Shock 2012;37:210-8. CrossRef

12. Majetschak M, Obertacke U, Schade FU, Bardenheuer M, Voggenreiter $\mathrm{G}$, Bloemeke B, et al. Tumor necrosis factor gene polymorphisms, leukocyte function, and sepsis susceptibility in blunt trauma patients. Clin Diagn Lab Immunol 2002;9:1205-11. CrossRef

13. Liedtke AJ, DeMuth WE Jr. Nonpenetrating cardiac injuries: a collective review. Am Heart J 1973;86:687-97. CrossRef

\section{ORİJINAL ÇALIŞMA - ÖZET}

\section{Acil serviste künt göğüs travmasına bağlı tip 2 ikinci derece ve üçüncü derece atriyoventriküler blok sıklığı: Çok merkezli çalışma \\ Dr. Banu Şahin Yıldız, ${ }^{1}$ Dr. Mehmet Ali Astarcıoğlu, ${ }^{2}$ Dr. Nazire Başkurt Aladağ, ${ }^{1}$ Dr. Ahmet Çağrı Aykan, ${ }^{3}$ Dr. Hakan Hasdemir, ${ }^{4}$ Dr. Alparslan Şahin, ${ }^{5}$ Dr. Mustafa Yıldız ${ }^{3}$}

${ }^{1}$ Dr. Lütfi Kırdar Kartal Eğitim ve Araştırma Hastanesi, Kardiyoloji Kliniği, İstanbul;

${ }^{2}$ Dumlupınar Üniversitesi Evliya Çelebi Eğitim ve Araştırma Hastanesi, Kardiyoloji Anabilim Dalı, Kütahya;

${ }^{3}$ Kartal Koşuyolu Yüksek İhtisas Eğitim ve Araştırma Hastanesi, Kardiyoloji Kliniği, İstanbul;

${ }^{4}$ Dr. Siyami Ersek Kardiyovasküler ve Torasik Cerrahi Eğitim ve Araştırma Hastanesi, Kardiyoloji Kliniği, İstanbul;

${ }^{5}$ Dr. Sadi Konuk Eğitim ve Araştırma Hastanesi, Kardiyoloji Kliniği, İstanbul

AMAÇ: Künt göğüs travmasını takiben tip 2 ikinci derece atriyoventriküler blok (Mobitz II) ve üçüncü derece atriyoventriküler blok iletim bozuklukları oldukça nadirdir. Dahası, travmayı takiben oluşan bu disritmilerden sorumlu patofizyolojik mekanizmalar henüz tam olarak anlaşılamamıştır. Biz travma ile ilişkili bu disritmilerin sıklığını tespit etmeyi amaçladık.

GEREÇ VE YÖNTEM: Acil servise başvuran ardışık Mobitz II ve üçüncü derece atriyoventriküler bloklu 253 hasta, Ocak 2012 ile Mart 20 I 3 tarihleri arasında değerlendirildi. Mobitz II ve üçüncü derece atriyoventriküler blok ve travma ile ilişkili sadece dört hasta mevcut çalışmaya alındı. Atriyoventriküler blok düzeyi elektrokardiyografik özelliklere göre tanımlandı.

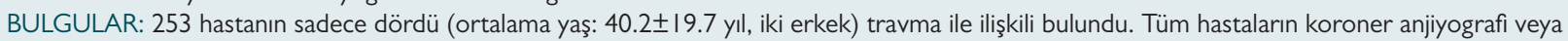
çok kesitli bilgisayarlı tomografi ile koroner arterleri normal saptandı. Kalıcı kalp pili üçüncü derece atriyoventriküler bloğu olan iki hastaya takıldı. Hastaların hiçbirinde koroner arter hastalı̆̆ı ve hipertansiyon yoktu.

TARTIŞMA: Literatürde künt göğüs travmasına bağı iletim kusurları nadir görülen klinik olgulardır ve genellikle geçici olmaktadır. Bu nedenle künt göğüs travması olan hastaların başvuru sırasında ve takiplerde atriyoventriküler blok açısından elektrokardiyografik değerlendirilmesi gerekir. Anahtar sözcükler: Elektrokardiyografi; künt göğüs travması; üçüncü derece atriyoventriküler blok; tip 2 ikinci derece atriyoventriküler blok (Mobitz II).

Ulus Travma Acil Cerrahi Derg 2015;2I(3):193-196 doi: 10.5505/tjtes.2015.04763 